\title{
Views of Medical Teachers Regarding the Need of Training or Course on Medical Education
}

\author{
SM Idris Ali, Md. Humayun Kabit Talukder, Momena Khatun ${ }^{3}$, Rowsan Ara Khanom ${ }^{4}$, Md. Abdal Miah, \\ Md. Wakil Ahmed', Golam rabbi, Md. Touhidur Rahman', Md. Abdul wahab Khan'.
}

\begin{abstract}
Background

Medical education in Bangladesh is poorly assessed and there is a general lack of documented knowledge about the challenges facing this field and the needs for its development. This study aimed to assess the need of medical education training or course for the teachers of medical colleges.
\end{abstract}

\section{Methods}

A quantitative study based on a self-administered questionnaire of a purposive sample of 204 teachers of different medical colleges was conducted from $1^{\text {st }}$ July, 2011 to $30^{\text {th }}$ June 2012 to explore their views regarding the training or course in medical education.

\section{Results}

The study revealed that majority (98.5\%) of respondents showed their interest for training or course on medical education. Among them $61 \%$ preferred a regular course, $29 \%$ desired for training program and $10 \%$ for refresher training on medical education. Most of the respondents (68\%) agreed that there are some barriers to participate in a training or course on medical education.

\section{Conclusions}

The existing medical education system face significant problems and it needs important and comprehensive improvements in or course on medical education. There is a need for further research in this field to explore the identified problems in a more in-depth manner in order to better understand of the problems and needs of training or course on medical education.

\section{Introduction}

The need of Medical Education training is to produce medical specialists who have acquired the requisite knowledge, skills and professional attributes. Medical education has to train future doctors in a way that they are capable of managing the health problems of those who seek their services in competent and humane manner. Additionally, medical education should be aligned with the needs of society. This change of focus from teaching to

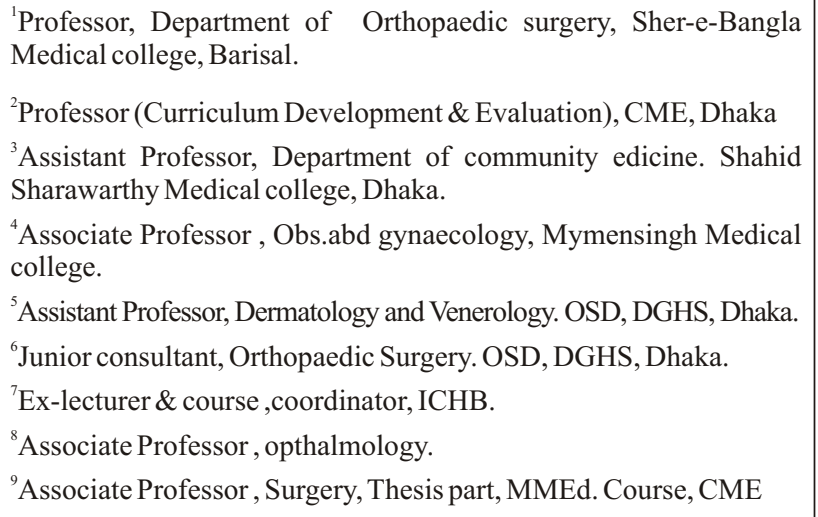

Address of correspondence: Professor SM Idris Ali., E-mail idrisali_bkzmc@yahoo.com Tel.01711155034. learning re-quires a whole new array of teaching skills on the part of the teacher (1).

The attribution of different "weightings" to the two principal functions of teachers in medical education (researching and teaching) means the professional prestige of teaching staff derives almost exclusively from their research activity and scientific output; it is their dedication to research which secures them stability in their profession, often to the detriment of teaching (2).

In medical education teachers are also expected to take decisions - based on their own knowledge of education to adopt for, the way the content of their subject relates with content from other domains, the learning situations they wish to construct, the teach-ing materials best suited to the objectives pursued(3).

The quality of medical education is constrained by inadequate number of trained medical teachers. The majority of teachers employed are untrained and very few of medical colleges in non-government sectors have no proper medical education departments which offer teacher's training. Even those institutes which claim to have established medical education units are providing rudimentary teachers training which fails to help teachers in 
transfer of proper relevant information in an integrated manner. $(4,5)$.

The specific ability of the medical teachers to encourage and support his or her students in their learning. Writing in defense of a form of teacher training which goes beyond the mere improvement of the teacher's organizational and managerial abilities in the act of teaching. The training of medical educa-tion of teachers the concept of "construction of teach-ing abilities and the teaching skills of medical teachers/researchers", stressing the dual function (teaching and research) of these professionals.".(6)

\section{Background}

The first organized effort for the need of medical education training or course in teaching and learning processes in medicine was developed as the Project on Medical Education at the University of Buffalo in 1955. According to Miller, this was, "the flowering of an idea whose time had come." These efforts of these pioneers did not progress without obstacles but the ground was ripe for the germination of the seed. While there were many earlier attempts at looking at teaching and learning in medical schools, including an essay on this subject by the German surgeon Theodor Billroth in 1876(7), and the references in the Flexner Report in 1910, these did not lead to any sustained activity.

The views of teachers about the experience on medical education was followed by the establishment of the two best known Departments in Medical Education in the 1960s, the Centre for Medical Education Development at the University of Illinois in Chicago and the Department of Medical Education at the University of Southern California. The former was headed by Dr George Miller and the latter by Dr. Steve Abrahamson, the two leaders of the Buffalo Project (8).

WHO is providing opportunities for fellowship program for persons qualified in basic or clinical disciplines to gain training in educational science. Two regional Teacher Training Centers (TTC) were designated for the South East Asian Region in 1971: one at the University of Peradeniya in Sri Lanka and the other at Chulalongkorn University in Bangkok. (9)

Flexner's recommendations laid the foundation for training on medical education that re?ected both the structure of medical education and the perspectives embedded in that structure. Teachers' responsibility as experts was to transmit their knowledge to learners; students' responsibility was to learn and master it. Medical education is hardly unique in its thick mantle of self referential analysis and professional judgment, but it is impressive for the relentless manner in which its practitioners investigate their own methods and outcomes. (10)

\section{Method}

Study Design: Descriptive type of Cross-sectional study.

Study period: 1 year (July 2011-June 2012).

Study population: Teachers of different medical colleges.
Study place : Two public (Sir Salimullah medical college ,Dhaka and Sher-E-Bangla Medical College, Barisal) and two non-government medical colleges (Northern medical college, Dhaka and IBN Sina Medical college,Dhaka) were selected according to the convenience of the researcher.

Sampling unit: Each teacher of medical colleges.

\section{Selection criteria:}

- Those teachers of all disciplines who were willing to respond.

- Those that was present at the time of data collection.

Sample size: A total of 204 teachers were included in the study Sampling technique: Convenience purposive sampling.

Research Instruments: Semi-structured and selfadministered questionnaire.

Pre-testing : The instrument was finalized after pretesting upon the teachers other than the study area. Pretesting was done among 20 teachers of NITOR, Dhaka.

Data collection procedure : Investigator himself collected all the data. Data were collected from those teachers who were available at the time of data collection. The teachers returned the filled up questionnaire on the same day or after some days.

Data processing and analysis: Quantitative parts of data were checked and edited after collection, and then was processed and analyzed by using SPSS 11.5 software package. Data is presented in the form of table and graphs to show the findings.

Ethical Implication : This research was conducted after getting prior permission from all concerned authorities. All respondents participated voluntarily in this study. Confidentiality and anonymity of the responses of the respondents were maintained.

\section{Results}

Table 1: Distribution of the respondents by their designation and type of medical college. $n=204$

\begin{tabular}{|l|c|c|c|c|}
\hline Designation & \multirow{2}{*}{$\begin{array}{c}\text { No. of teaches } \\
\text { of the } \\
\text { teachers }\end{array}$} & $\begin{array}{c}\text { Nom gov teachers } \\
\text { medical colleges }\end{array}$ & \multicolumn{2}{|c|}{ modical colleges } \\
\cline { 4 - 6 } & Teachers & $\%$ \\
\hline Professor & $14(6.86 \%)$ & $9(4.41 \%)$ & 23 & 11.28 \\
\hline $\begin{array}{l}\text { Associate } \\
\text { professor }\end{array}$ & $51(25 \%)$ & $8(3.92 \%)$ & 59 & 28.92 \\
\hline $\begin{array}{l}\text { Assistant } \\
\text { professor }\end{array}$ & $57(27.94 \%)$ & $15(7.35 \%)$ & 72 & 35.29 \\
\hline Registrar & $27(13.23 \%)$ & $6(2.94 \%)$ & 33 & 16.17 \\
\hline Lecturer & $5(2.45 \%)$ & $12(5.88 \%)$ & 17 & 8.33 \\
\hline Total & $154(75.5 \%)$ & $50(24.5 \%)$ & 204 & 100.0 \\
\hline
\end{tabular}

Table 1 shows among 204 respondents highest number teacher belongs to Government medical colleges $75.5 \%$, out of which assistant professor $27.94 \%$ and associate professor is $25 \%$. 
Table 2: Distribution of the respondents as per their desire to participate or enroll in training/course course in medical education

$(n=204)$

\begin{tabular}{|c|c|c|}
\hline $\begin{array}{l}\text { Desire of the respondent to } \\
\text { participate or enroll in training/ } \\
\text { course on medical education }\end{array}$ & Frequency & Percent \\
\hline Yes & 201 & 98.5 \\
\hline No & 3 & 1.5 \\
\hline Total & 204 & 100.0 \\
\hline
\end{tabular}

Table 2 shows that among 204 respondents 201 (98.5\%) had interest to participate or enroll in training/course/refresher training on medical education.

Table 3: Distribution of respondents as per their views regarding the duration of training program $(\mathrm{n}=78)$

\begin{tabular}{|l|c|c|}
\hline Duration of training program & Frequency & Percent \\
\hline One Month & 15 & 19.23 \\
\hline Two Months & 5 & 6.41 \\
\hline Three Months & 34 & 43.59 \\
\hline Six Months & 19 & 24.36 \\
\hline More then six months & 5 & 6.41 \\
\hline Total & 78 & 100.0 \\
\hline
\end{tabular}

Table 3 shows that among 78 respondents who wanted to enroll on a training program on medical education the majority believe that duration of the training should be three months $(43.59 \%)$.

Table 4: Distribution of the respondents as per their opinion about barriers to participate in a course on medical education. $\mathrm{n}=123$

\begin{tabular}{|c|c|c|}
\hline $\begin{array}{l}\text { Barriers to participate in a } \\
\text { course on medical education }\end{array}$ & Frequency & Percent \\
\hline Yes & 83 & 67.48 \\
\hline No & 40 & 32.52 \\
\hline Total & 123 & 100.0 \\
\hline
\end{tabular}

Table 4 shows opinion of 123 respondent (Who showed interest to participate in a course on medical education) regarding the barriers to participate in a course on medical education. Majority of the respondents( $67.45 \%)$ believes there are barriers to participate in a course on medical education.

Table 5: Distribution of the respondents as per their views about the reasons behinds the barriers to participate in the course on medical education

$(\mathrm{n}=123)$

\begin{tabular}{|l|c|c|}
\hline $\begin{array}{l}\text { Reasons behind the barriers to } \\
\text { participate in the course on } \\
\text { medical education. }\end{array}$ & Frequency & Percent \\
\hline $\begin{array}{l}\text { Have less opportunity for } \\
\text { deputation }\end{array}$ & 46 & 56.1 \\
\hline $\begin{array}{l}\text { Have less opportunity for study } \\
\text { leave }\end{array}$ & 36 & 43.9 \\
\hline Have crossed the age limit & 16 & 19.5 \\
\hline Private practice will be hampered & 26 & 31.7 \\
\hline Family will be disturbed & 25 & 30.5 \\
\hline
\end{tabular}

\section{*Multiple responses}

Table 5 shows the opinions of the respondents about the reasons behind the barriers to participate in the course. $\operatorname{Most}(56 \%)$ of them believed that there is less opportunity for deputation, $44 \%$ gave opinion of less opportunity for study leave, $20 \%$ t have crossed the age limit, $32 \%$ believed that private practice will be hampered and $31 \%$ thought that their family will be disturbed.

Table 6: Distribution of the respondents as per their suggestions for training program

$(n=78)$.

\begin{tabular}{|l|c|c|}
\hline $\begin{array}{l}\text { Suggestions for training } \\
\text { program on medical education }\end{array}$ & *Frequency & Percent \\
\hline $\begin{array}{l}\text { Centre for medical education can } \\
\text { arrange more training }\end{array}$ & 55 & 70.15 \\
\hline $\begin{array}{l}\text { Medical college can arrange } \\
\text { more training through their own } \\
\text { medical education unit }\end{array}$ & 53 & 67.95 \\
\hline The training should be evaluated & 25 & 32.6 \\
\hline $\begin{array}{l}\text { Training should be provided to } \\
\text { those who own their subject }\end{array}$ & 36 & 46.15 \\
\hline
\end{tabular}

\section{*Multiple responses}

Table 6 reveals some suggestions regarding training program on medical education. Most $(70 \%)$ of the respondents gave opinion that the Centre for medical education can arrange more training, $68 \%$ gave opinion that the medical college can arrange more training through their own medical education unit, $33 \%$ gave opinion about the evaluation of training programme and $46 \%$ believed that the training should be provided to those who own their subject.

\section{Discussion}

This cross sectional descriptive study was carried out among the teachers working in two government and two non government medical colleges. The information was collected from the teachers of these medical colleges, about their views regarding the need of training or course on Medical Education for the teachers of medical colleges. 
Medical Education is a tertiary level specialized professional education with three functional components knowledge, skill and attitude (KSA) and two dimensions, service and science is very much essential. This education needs special management as well as training from specialized institution.(11)

It is traditionally believed that "Teachers are born, not made". This is a reflection of the concept that "teaching skill is a set of indefinable qualities that are innate and perhaps genetically determined and incapable of improvement" However this hypothesis "teaching is now regarded as a highly complex skill. This has been broken down to meaningful and acquirable component parts or microskills". (8).

The teachers shared their experiences about need of training for medical teachers said that training help teachers to learn how to teach students, design lesson plan, and how to deal with students. The literature also support this position as Rizvi and Elliott (2007) and Harries (2006) emphasized on teachers training and course both in professional development courses and in every day school activities, which uplift students' outcomes in the result the school becomes successful. The whole discussion highlighted that teachers are fully aware about the role of professional development and teachers' capacity building for school improvement.(12)

"The question of how teachers learn to teach is clearly basic to the enterprise of teacher education. Only recently, however have researchers begun to systematically frame and study this question. For the most part, attention in teacher education has traditionally been focused on what teachers need to know and how they can be trained, rather than on what they actually know and how that knowledge acquired. The perspective, in other words, has been from the outside, external to the teachers who are learning and the processes by which they are educated" (13).

"It is curious that so many of our most important responsibilities are undertaken without significant preparation. Marriage, parenthood and teaching (in medical schools) are probably most ubiquitous illustrations". It is necessary for the present day teacher to be aware of and become part of far reaching changes that are taking place in medical education. The changes are: shift from conventional role of teacher, changes in learning styles, innovative curriculum models and changes in assessment philosophy, methods and tools [14].

Many researchers have discussed barriers to enroll in a teaching course, which can be categorized as physical barriers, attitudinal barriers and structural barriers. Physical barriers are those factors in the individual life circumstances at any given time. Numerous authors and researchers have identified physical barriers which include : Lack of time because of job responsibilities, family and child care responsibilities, difficulty in paying course fee and fear of losing benefits, difficulty with academic reading and writing, difficulty with English if this is not the learners first language(15).

Attitudinal barriers refer to attitude self perceptions about one self as a learner. Authors and researchers have identified attitudinal barriers as: negativity due to unpleasant past experience, lack of emotional and physical energy, being nervous about going back to classroom and concern about not being able to keep up academically. These results in the health professional have low aspirations and doubts about the value of continuing professional development, low self esteem, lack of confidence, both generally and in relation to learning and lack of trust in formal institution(16).

Structural barriers to post graduate education and continuing development can be regarded as being synonymous with institutional or organizational barriers. These are the practices, procedures and policies that place limits on opportunities for potential adult learners to participate. Structural barriers have been identified as a lack of transport and limited opportunities for learning near to the potential learner's place of residence. Staff shortage may limit opportunities for learning. Lack of knowledge about learning opportunities; prohibit entry requirements to postregistration programs, lack of appropriate programs and late advertisements of professional educational events are cited as barriers to post graduate education and continuing professional development. The lack of coherent staff development plans, difficulty in obtaining study leave (17).

In a study about barriers to job related training conducted by Sussman, (18) identified three main types of barriers to participate in job related training. These are situational, institutional and depositional or psychological. Situational barriers arise from one's situation in life at a given time- for example, being to busy at work, financial constraints, family responsibilities or lack of child care and language or health problem. Institutional barriers consists of established practices and procedures that exclude or discourage participation, such as high tuition fee, entrance requirements, limited course offerings, or course offered at inconvenient times or locations.

Dispositional barriers involve attitudes and opinions towards learning, as well as perception of oneself as a learner. The findings of the present study are more or less similar to the study in certain aspects of the barrier mentioned in the study above.

\section{Conclusion}

The field of medical education should be expanded and the resources, training material, separate institution are very much needed for training purpose only. There should be a complete separate institute which can provide MMEd. Course. Medical teachers must go through training or courses on teaching methodology. Anybody who has been confirmed as a teacher should consider for training or course on medical education. Numbers of teacher should be increased for providing training. For all teachers training on medical education is essential for better teaching and research. 


\section{References}

1. Burdick WP, Morahan PS \& Norcini JJ. Capacity building in medical education and health outcomes in developing countries: the missing link: Educ Health, 2007, 20 (3), 43-67.

2. Dalziel, J. Practical eTeaching Strategies: PredictObserve-Explain, Problem Based Learning and Role Plays. Sydney: 2010, LAMS International, viewed from www.practicaleteachingstrategies.com

3. Schormair C, Swietlik U, Hofmann U, Wilm S \& Witte L. Ten statements on the motivation of medical teachers to teach. Medical Teacher. 1992,14(.4) 283286.

4. Miller GE. Teaching and learning in medical school, Harvard University Press, Cambridge. 1961, 22, 90154.

5. Ealos C. Life long learning South African Journal of physiotherapy, 2001, 57 (3).22

6. Kogan, M. Self-evaluation, education of teachers and quality in higher education. In C. Reimão (org.), $A$ formação pedagógica dos professores do ensino superior. Lisboa: Edições Colibri. 2001.101-109.

7. Fuller, FF. Concerns for teachers, A developmental conceptualization, American Educational Research Journal. 1969, 6.. 207-226.

8. Miller GE. Teaching and learning in medical school, Harvard University Press, Cambridge. 1961. 22, 90154.

9. Humbold W V T. The following text was originally published in Prospects:the quarterly review of comparative education (Paris, UNESCO:

International Bureau of Education). 2000. XXIII, 3/4,
61323. OUNESCO:International Bureau of Education, This document may be reproduced free of charge as long as acknowledgement is made of the source (17671835).

10. Kinley CE, \& Langley GR \& Halifax NS. Observations on a Medical Teacher Training Program. Canad. Med. Ass. J. 1966, 94 . 76-90.

11. Rizvi M, \& Elliot R. 2007, Enhancing and sustaining teacher professionalism in Pakistan. Teachers and Teaching: Theory and Practices. 2007, 13, (1) . 5-19.

12. Harris, A . Leading Change in School in Difficulty. Journal of Educational Change. 2006.7. 9-18.

13. Brian DH, Mathieu A, Delphine A, Spogmai A, Glen B, Niall B, Bernard C, Philippe K, et al Medical Education. 2011.45.95106.

14. Harden RM \& Crosby J. The Good Teacher is more than a Lecturer- twelve roles of good teacher, Medical Teacher. 2000.22.(4) 98-132.

15. Ferguson A. Evaluating the purpose and benefits of continuing education in nursing and the implecations for the provision of continuing education for the cancer nurses. Journal of advanced nursing. 1994.19; 640646.

16. Yeun F. Continuing nursing education- some issues. Journal of advanced nursing; 1991. 16, 1233-1237.

17. Nolan F. Continuing professional educationIdentifying the characteristics of an effective system. Journal of advanced nursing; 1995. 30, 427-475.

18. Sussman D. Barriers to job related training, Perspectives statistics Canada catalog. no. 75-001-XIE ;2002. 